\title{
Penerapan Break Even Point Pada Pabrik Rice Processing Complex (Rpc) Anabanua Kabupaten Wajo
}

\author{
Sukiman ${ }^{1}$ \\ sukimanbachtiar@yahoo.co.id \\ Hasanuddin ${ }^{2}$ \\ achankbagu.bone@gmail.com
}

\begin{abstract}
This research aimed to provide an illustration of the production amount in order to achieve the value of the break even point.Analysis method used was descriptivequantitative. The data were analysed using the Break Even Point analysis.The research results revealed that; (1) RPC as a rental service provider of the rice mill of $\mathrm{Rp} .250$ per $\mathrm{kg}$ which has the value of the break even points of production of $27.373 .889 \mathrm{~kg}$ per year. Its exceed the maximum production capacity of the machine of 25,920,000 kg per year; (2) RPC was not able to reach the value of the break even point of production was only cooperated with one business partner as the use of rice milling services with the highest capacity of supply of 520,660 kg per year;

Key Word: Rice Processing Complex,Break Even Point, Production Kapacity
\end{abstract}

\begin{abstract}
Abstrak
Penelitian ini bertujuan menggambarkan jumlah produksi RPC dalam mencapai nilai titik impas sebagai penyedia jasa penggilingan gabah. Metode penelitian digunakan kuantitatif deskriptif. Data di olah dengan menggunakan analisis Break Event Point. Hasil penelitian ini menunjukkan bahwa; (1) RPCsebagai penyedia jasa sewa penggilingan padi dengan harga sewa Rp. 250 per kgmemiliki nilai titik impas produksi sebesar 27.373.889 kg per tahun melebihi kapasitas maksimum produksi mesin RPC sebesar 25.920.000 kg per tahun; (2) RPC tidak dapat mencapai nilai titik impas produksinya yang hanya bekerjasama dengan satu mitra pengusaha yang memiliki kemampuan pasokan tertinggi sebesar 520,660 kg per tahun

Kata kunci:Rice Processing Complex ,Break Even Point, Kapasitas Produksi
\end{abstract}

\section{Pendahuluan}

Produksi padi di Kabupaten Wajo pada tahun 2014 sebesar 731.950 ton, hal ini meningkat daritahun 2013 dari produksi sebesar 637.808 ton dengan tingkat rata-rata produktivitas sebesar 5,3 ton per hektar. Pemerintah daerah Kabupaten Wajo dalam menjaga kualitas produksi dan stabilitas harga beras petani, pada tahun 2003 telah mengeluarkan kebijakan dengan membangun pabrik Rice Processing Complex (RPC) di Anabanua Kabupaten Wajo yang memiliki kapasitas optimal produksi 25.920 ton beras per tahun atau kemampuan produksi perjamnya sebesar 4 ton dengan maksimal produksi 18 jam per hari dengan rendemen 65\%. RPC dengan mesin dan konstruksinya menggunakan

\footnotetext{
1 Peneliti "Embrio Research and Consulting" Makassar 2015 - sekarang

2 Dosen Tetap Fakultas Ekonomi, Universitas Ichsan Gorontalo, Prodi Akuntansi
} 
lisensi Korea Selatan memiliki kapasitas pengering 80 ton per hari dan kapasitas silo 900 ton gabah. Efisiensi gabah hilang melalui pemrosesan di RPC dinyatakan hanya antara $5-10 \%{ }^{3}$

Pada dasarnya keberadaan pabrik penggilingan padi RPC di kabupaten Wajo dapat menjadi pendorong meningkatnya kualitas produksi stabilitas pasokan bahan baku gabah di Kabupaten Wajo. Namun faktanya, peran tersebut tidak dapat dilaksanakan dengan baik dikarenakan pengelolaan RPC Anabauna Kabupaten Wajo yang masih belum optimal. Hal ini terlihat pada pendapatan dan jumlah produksi RPC dalam 5 tahun terakhir yang masih sangat rendah dibandingkan kapasitas produksi optimal mesin yang dimiliki sebesar 25.920 to per tahun. Adapun hasil produksi RPC pada tahun 2011 sebesar 500 ton Rp. , 2012 sebesar 520,66 ton, 2013 sebesar 128 ton, 2014 sebesar 162,3 ton dan Juli 2015 sebesar 8,06 ton. Rendahnya produksi tersebut yang masih sangat jauh dari kapasitas maksimal mesin yang dimilikinya berdampak pada nilai pendapatan yang diperoleh pada RPC. Selain dari hal tersebut, keterbatasan dari pihak manajemen pengelola RPC dalam mengambil keputusan secara mandiri karena RPC masih dibawahi langsung oleh dinas perindustrian, koperasi dan UMKM Kabupaten Wajo. ${ }^{4}$

Seiring rendahnya produksi pada pabrik penggilingan RPC, pemerintah dan pihak pengelola sering mendapat sorotan oleh masyarakat maupun anggota DPRD Kabupaten Wajo. Pada Kompasiana, juga pernah memberitakan tentang pabrik RPC yang dibangun sejak tahun 2004 dengan biaya sekitar Rp 30 miliar di Anabanua Kabupaten Wajo yang merugi sejak tahun pendiriannya dan dikhawatirkan akan menjadi beban pemerintah daerah. Hal ini terungkap setelah pihak DPRD Kabupaten Wajo mengkaji sebuah rencana kerjasama Pemkab Wajo dengan salah satu perusahaan swasta berkaitan dengan pengoperasian RPC Anabanua Kabupaten Wajo, yang dinilai justru tetap akan membebani pihak pemerintah daerah. $^{5}$

NCRI, dalam penelitiannya menemukan analisis sensitivitas dari dampak perubahan beberapa input dasar seperti investasi dalam peralatan, biaya bahan bakar, biaya tenaga kerja, biaya bahan baku gabah dan harga jual beras diproses pada titik impas menunjukkan bahwa peningkatan biaya input akan meningkatkan nilai titik impas, sehingga menghambat pencapaian nilai titik impas awal, sedangkan kenaikan harga akan menurunkan nilai titik impas, dan dengan demikian mendukung profitabilitas usaha. ${ }^{6}$

Untuk mendukung keputusan operasi dalam menentukan kapasitas produksi pada sebuah perusahaan dapat digunakan metode Break Even Point (BEP). ${ }^{7}$ Menurut Chopra dan Meindl, bahwa desain supply chain, perencanaan, dan keputusan operasi memberikan peranan yang penting dalam mementukan

\footnotetext{
${ }^{3}$ Dinas Koperasi, UMKM dan Perindustrian. Data Laporan Bulanan Produksi Penyewaan Penggilingan RPC, Pemerintah Kabupaten Wajo. 2015.

4 Ibid

5 Kompasiana. RPC Beras 7 Tahun Merugi Pemkab Wajo. (online), (http://regional.kompasiana.com/2011/05/27/rpc-beras-7-tahun-merugikan-pemkab-wajo368330.html, Diakses 16 April 2013), 2011.

6 NCRI. Report On Financial Analysis Of Rice Parboiling/Processing Systems In Bida Area. Niger State, Nigeria. 2006.

7 Yamit Z. Manajemen Operasi dan Produksi.Edisi kedua. Cetakan ketiga, , (Yogyakarta: EKONISA 2007), hal. 48
} 
keberhasilan atau kegagalan sebuah organisasi. ${ }^{8}$ Berdasarkan uraian pendahuluan diatas, maka dirumuskan permasalahanyaitu :berapa jumlah produksi RPC untuk mencapai nilai titik impas dalam satu periode produksi sebagai penyedia jasa sewa penggilingan gabah?

\section{Tinjauan pustaka}

\section{a. Rice Processing Complex (RPC)}

Untuk menghasilkan beras yang berkualitas dengan rendemen tinggi, maka diperlukan suatu teknologi pemrosesan beras yang lebih teliti dan maju. Teknologi ini dapat ditemui pada tempat pemrosesan beras modern yaitu RPC (Rice Processing Complex), proses yang dilakukan meliputi pengeringan, penyimpanan, pemisahan batuan, penggilingan, pemolesan/pemutihan, pemisahan pecahan beras, sortiran warna dan pengemasan, dimana semua proses kegiatan itu dilakukan dalam satu tempat. ${ }^{9}$ RPC (Rice Processing Complex) yang dibangun di Kecamatan Maniangpajo Kabupaten Wajo memiliki kapasitas produksi 25.920 ton beras pertahun atau dengan kemampuan produksi perjamnya sebesar 4 ton, maksimal produksi 18 jam perhari dengan rendemen 65 persen. ${ }^{10}$

Menurut Purwadaria, Rice Processing Complex atau biasa disingkat RPC (Kompleks Pengolahan Beras) adalah suatu pabrik pengolahan beras yang lengkap meliputi suatu kawasan usaha tani yang cukup untuk memasok gabah sebagai bahan baku RPC. Jiwa RPC adalah kawasan usaha tani yang dikelola secara serentak, terorganisir baik dengan masukan (input) usaha tani yang lancar dan teratur termasuk pengairan, benih, pupuk, obat-obatan, dan penggunaan mesin budidaya. RPC merupakan suatu usaha murni komersial yang menguntungkan karena itu memberi nilai tambah juga kepada petani peserta RPC. ${ }^{11}$

Hal tersebut diperkuat pendapat Sutrisno, menyatakan bahwa Konsep RPC sebetulnya adalah penyempurnaan dari sistem RMU modern yang dilengkapi dengan sistem pengeringan, penyimpanan dan pengemasan. ${ }^{12}$ Konsep ini, dikembangkan dalam rangka mengontrol alur proses pengolahan padi dalam suatu sistem terintegrasi, sehingga mutu produk dapat terjaga keseragaman serta nyata mengurangi susut bobot. Penggunaan sistem RPC ini secara umum diproyeksikan untuk dapat meningkatkan daya saing beras yang dihasilkan melalui mutu dan harga.

Dalam sebuah RPC menurut Daewon, terdapat 3 tahapan sehingga memberikan nilai tambah pada produksi beras yaitu Rice Drying \& Storage System (RDSS), Rice Processing System (RPS) dan Rice Quality Management System (RQMS). Rice Drying \& Storage System (RDSS)merupakan proses awal dari proses produksi beras.Pada proses produksi beras dimulai dari pengeringan gabah. Dimana pengeringan gabah yang baik sangat menentukan kualitas dari

${ }^{8}$ Chopra S., Meindl P. Supply chain management, planning and operation. Pearson prentice hall. 2007.

9 Sutrisno. RPC Sebagai Suatu Alternatif Peningkatan Mutu dan Nilai Tambah Beras. Makalah disajikan dalam Lokakarya Nasional Upaya Peningkatan Nilai Tambah Pengolahan Padi, Jakarta. 20-21 Juli 2004

${ }^{10}$ Daewon. Rice Processing Compex,(http://subin-cubin.blogspot.com/2008/06/riceprocessing-complex.html, diakses 1 Oktober 2013). 2008.

${ }^{11}$ Purwadaria H K. Teknologi Panen dan Pasca Panen Padi. Makalah disajikan dalam Lokakarya Nasional Upaya Peningkatan Nilai Tambah Pengelolaan Padi, Jakarta. 20-21 Juli 2004. ${ }^{12}$ Ibid 
beras yang dihasilkan, apabila pengeringan terlalu cepat dilakukan akan mengakibatkan tingginya gabah yang pecah saat proses kupas kulit ataupun pada saat proses poles dan sebaliknya pengeringan yang terlalu lambat mengakibatkan gabah busuk ataupun merubah warna dan rasa dari beras sehingga kualitasnya menjadi rendah. Untuk mencegah hal ini maka dikembangkan system RDSS. Kegiatan-kegiatan yang termasuk dalam proses RDSS adalah pembersihan gabah, pengeringan, dan penyimpanan gabah dalam kondisi simpan yang terkontrol. ${ }^{13}$

\section{b. Konsep Titik Impas}

\section{1) Kapasitas produksi}

Kapasitas produksi merupakan proses penetapan tingkat output atau kapasitas produksi secara keseluruhan guna memenuhi tingkat permintaan yang diperoleh dari peramalan dan pesanan dengan tujuan meminimalkan total biaya produksi. Kapasitas produksi merupakan jumlah maksimum output yang dapat diproduksi dalam satuan waktu tertentu. ${ }^{14}$ Perencanaan kapasitas produksi adalah proses dimana sebuah perusahaan menentukan tingkat ideal kapasitas, produksi, subkontrak, persediaan (inventory), stockouts, dan bahkan penetapan harga atas satuan waktu tertentu. ${ }^{15}$ Terdapat berbagai macam faktor yang harus diperhatikan dalam menentukan kapasitas produksi optimum. Faktor-faktor produksi tersebut disebut sebagai berikut:

a. Kapasitas bahan baku, yaitu jumlah bahan baku yang mampu disediakan dalam dalam waktu tertentu. Jumlah ini dapat diukur dari berbagai kemampuan suplier untuk memasok maupun kemampuan persediaan dari sumber bahan baku.

b. Kapasitas jam kerja mesin, yaitu jumlah jam kerja normal mesin yang mampu disediakan untuk melaksanakan kegiatan produksi.

c. Kapasitas jam tenaga kerja, yaitu jumlah jam tenaga kerja normal yang mampu disediakan.

d. Modal kerja, yaitu kemampuan penyediaan dana untuk melaksanakan proses produksi, seperti untuk membeli bahan baku, membayar upah dan lain sebagainya.

e. Jumlah atau kapasitas permintaan. ${ }^{16}$

Proses penentuan kapasitas produksi dapat digolongkan dalam tiga tingkatan perencanaan, yaitu:

a. Perencanaan jangka panjang, merupakan perencanaan lebih dari setahun yang menyangkut perencanaan produk baru, biaya perluasan dan sebagainya. Perencanaan jangka panjang ditetapkan oleh manajer puncak.

b. Perencanaan jangka menengah, merupakan rencana atara 3 sampai 18 bulan, menyangkut rencana penjualan, rencana produksi, rencana inventory, anggaran tenaga kerja dan sebagainya. Perencanaan jangka menengah ditetapkan oleh Manajer Operasi.

${ }^{13}$ Daewon.Rice Processing Compex,(http://subin-cubin.blogspot.com/2008/06/riceprocessing-complex.html, diakses 1 Oktober 2013). 2008.

${ }^{14}$ Yamit Z. Manajemen Operasi dan Produksi.Edisi kedua. Cetakan ketiga, (Yogyakarta: EKONISA,. 2007), hal. 49

${ }^{15}$ Chopra S., Meindl P. Supply chain management, planning and operation. Pearson prentice hall. 2007.

\footnotetext{
${ }^{16}$ Ibid
} 
c. Perencanaan jangka pendek, merupakan rencana kurang dari tiga bulan yang menyangkut penugasan, pemesanan, penjadwalan. Perencanaan jangka pendek ditetapkan oeh manajer operasi bersama dengan supervisor dan operator. ${ }^{17}$

\section{2) Break even point}

Perusahaan salah satu tujuannya adalah untuk mendapatkan keuntungan. Sebelum memproduksi atau menghasilkan suatu produk barang maupun jasa, perusahaan terlebih dahulu harus merencanakan besar laba yang ingin diperoleh agar besaran perolehan laba mudah ditentukan, maka salah satu cara adalah perusahaan harus mengetahui terlebih dahulu berapa nilai titik impas dalam sekali produksinya.

Perencanaan kapasitas produksi penting untuk ditentukan agar dapat mengetahui kebutuhan pada sebuah perusahaan dalam sekali produksi. Untuk menentukan kapasitas produksi optimum dapat digunakan metode break even point (BEP) dimana suatu keadaan total pendapatan besarnya sama dengan total biaya $(\mathrm{TR}=\mathrm{TC}) .{ }^{18}$ Analisis titik impas dapat juga digunakan untuk mengetahui jumlah produksi dan penjulan minimal agar perusahaan tidak mengalami kerugian. ${ }^{19}$ Analisis titik impas (break event point) merupakan suatu proses dimana nilai suatu parameter seperti komponen dari biaya tetap, harga jual produk, ataupun MARR (Minimum Attractive Rate of Return) divariasikan dan nilai dimana kinerja finansial dari investasi mencapai titik balik (dari untung menjadi rugi, atau sebaliknya) merupakan titik impas. ${ }^{20}$

Pada biaya total (total cost), biaya produksi umumnya dibagi atas dua komponen yaitu komponen biaya tetap (fixed cost) dan komponen biaya tidak tetap (variabel cost). Jumlah dari biaya tetap dengan biaya tidak tetap dinyatakan dalam biaya total atau biaya pokok. ${ }^{21}$ Biaya tetap (Fixed Cost),merupakan total pengeluaran yang dibayarkan meskipun tidak ada output yang diproduksi. ${ }^{22}$ Adapun komponen biaya dalam biaya tetap seperti biaya sewa bangunan, biaya penyusutan, biaya gaji pegawai tetap, biaya pajak dll. ${ }^{23}$ Biaya tidak tetap (variabel Cost), merupakan biaya yang dikeluarkan oleh perusahaan tergantung pada jumlah produk yang diproduksi. ${ }^{24}$ Pengeluaran yang dibayarkan berubah bersama dengan tingkat output seperti bahan baku atau bahan mentah, upah, dan bahan bakar serta semua termasuk biaya yang titdak tetap. ${ }^{25}$ Total pendapatan (Total Revenue),pada sebuah perusahaan umumnya diperoleh dari penjualan produk yang dihasilkan. ${ }^{26}$

\section{Pembahasandan Analisis}

\footnotetext{
${ }^{17}$ Ibid

${ }^{18}$ Yamit Z. Manajemen Operasi dan Produksi.Edisi kedua. Cetakan ketiga, (Yogyakarta. EKONISA 2007), hal. 49

${ }^{19}$ Patiwiri A W. Teknologi Penggilingan Padi. Jakarta, Gramedia Pustaka Utama. 2006

${ }^{20}$ Salengke. Engineering Economic. Techniques for Project and Business Feasibility Analysis. Makassar, Identitas UNHAS. 2012

${ }^{21}$ Ibid

${ }^{22}$ Samuelson, \& Nordhaus. Ilmu Ekonomi Mikro. (Jakarta, PT. Media Global Edukasi. 2003), hal. 73

${ }^{23}$ Harnanto, Analisa Laporan Keuangan. (Yogyakarta, BPFE, 1987), hal. 42

${ }^{24}$ Ibid

${ }^{25}$ Ibid

${ }^{26}$ Ibid
} 
Setiap perusahaan atau industri memiliki tujuan untuk memperoleh keuntungan. Untuk mencapai tujuan tersebut, sebuah perusahaan atau industri harus menjaga kelancaran produksi sehingga dapat terjaga keberlangsungan usaha. Pabrik penggilingan padi RPC Anabanua Kabupaten Wajo dalam hal ini, penting menjaga keseimbangan ketersediaan jumlah bahan baku (gabah) produksi dengan kapasitas produksi mesin yang dimiliki. Baik jika difungsikan sebagai penyedia jasa sewa penggilingan padi maupun jika difungsikan untuk memproduksi beras jual.

Untuk menciptakan keseimbangan pada pabrik penggilingan padi RPC Anabanua Kabupaten Wajo agar tidak mengalami kerugian yang berkepanjangan sebagaimana kondisi saat ini yang telah terjadi dari sejak pendiriannya tahun 2003 silam. Maka pabrik penggilingan padi RPC penting untuk menetakan jumlah minimal produksi dalam satu tahun dengan menghitung nilai titik impas produksi agar tidak rugi dan untung. Bahwa Nilai titik impas merupakan pendapatan (revenue) sama dengan biaya (cost). ${ }^{27}$ Analisis nilai titik impas juga dapat digunakan untuk mengetahui jumlah produksi dan penjualan minimal agar perusahaan tetap tidak rugi dan tidak untung. ${ }^{28}$

Pada pabrik penggilingan padi RPC Anabanua Kabupaten Wajo, biaya yang dikeluarkan dalam operasional produksi terbagi 2 yaitu, Biaya tetap dan Biaya Tidak tetap. Biaya tetap (Fixed Cost)merupakan biaya pada RPC yang tidak terpengaruh oleh berbagai variasi dalam jumlah output seperti, biaya penyusutan mesin, biaya gaji tetap karyawan, biaya bunga modal dan biaya pajak. Dan Biaya tidak tetap (variabel cost atau operating cost) merupakan biaya-biaya operasional pada RPC yang berubah sesuai dengan jumlah ouput yang dihasilkannya seperti, biaya bahan bakar, biaya listrik, biaya bahan baku dan biaya pemeliharaan mesin. $^{29}$

\section{Analisis titik impas produksi untuk jasa sewa giling gabah}

Analisis titik impas produksi untuk jasa sewa giling gabah merupakan perhitungan nilai titik impas pada kondisi RPC berfungsi sebagai penyedia jasa sewa penggilingan gabah menjadi padi.

\section{a. Biaya tetap}

\section{1) Biaya gaji karyawan tetap}

Pada Tabel 1 biaya gaji karyawan RPC pada tahun 2012-2014 terdiri dari gaji bulanan sebesar Rp. 300.000,- dan biaya biaya lauk pauk perharinya sebesar Rp. 12.500,-. Jumlah total karyawan dengan penanggungjawab pengelola RPC sebanyak 7 orang. Namun sejak tahun 2015 jumlah karyawan RPC sudah berkurang dan sisa 3 orang pengelola yang terdiri dari 1 orang sebagai penanggungjawab dan dibantu 2 orang sebagai kepala produksi dan operator. Selain jumlah pengelola yang berkurang, biaya lauk pauk pun juga sudah dihilangkan sehingga mereka hanya menerima gaji bulanan saja sebesar Rp.

\footnotetext{
${ }^{27}$ Patiwiri A W. Teknologi Penggilingan Padi. (Jakarta, Gramedia Pustaka Utama. 2006), hal 82.

${ }^{28}$ Ibid

${ }^{29}$ Yamit Z. Manajemen Operasi dan Produksi.Edisi kedua. Cetakan ketiga, (Yogyakarta: EKONISA. 2007), hal. 48.
} 
300.000,-. Berikut Tabel 1, biaya gaji pengelola RPC Anabanua Kabupaten Wajo tahun 2012 sampai tahun 2015.

Tabel 1. Biaya gaji pengelola RPC Anabanua Kabupaten Wajo tahun 20122015

\begin{tabular}{|c|c|r|r|}
\hline \multirow{2}{*}{ TAHUN } & \multicolumn{3}{|c|}{ Biaya Gaji Pengelola RPC } \\
\cline { 2 - 4 } & Gaji (Rp) & Uang Lauk Pauk (Rp) & \multicolumn{1}{c|}{ TOTAL (Rp) } \\
\hline 2012 & 25.200 .000 & 31.500 .000 & 56.700 .000 \\
\hline 2013 & 25.200 .000 & 31.500 .000 & 56.700 .000 \\
\hline 2014 & 25.200 .000 & 31.500 .000 & 56.700 .000 \\
\hline 2015 & 10.800 .000 & - & 10.800 .000 \\
\hline
\end{tabular}

Sumber Data: Dinas Koperasi, UMKM dan Perindustrian, diolah 2015

\section{2) Biaya penyusutan}

Dalam penghitungan biaya penyusutan mesin dan biaya penyusutan bangunan pada RPC Anabanua Kabupaten Wajo digunakan model penghitungan Straight Line dimana model ini merupakan model penyusutan yang memperkirakan bahwa nilai dari suatu aset menyusut pada persentase yang tetap setiap periode selama umur ekonomis atau selama masa pengembalian modal (recovery period) aset tersebut (Salengke, 2012). Nilai ekonomis pada perhitungan biaya penyusutan untuk mesin dan bangunan pada pabrik RPC Anabanua menggunakan umur ekonomis 20 tahun dan nilai akhir aset sama dengan 0 (nol). Berikut ini penghitungan biaya penyusutan mesin dan bangunan pada pabrik penggilingan padi RPC Anabanua Kabupaten Wajo.

\section{Biaya penyusutan mesin}

$$
\begin{gathered}
\mathrm{D}_{\mathrm{SL}}=\frac{\mathrm{I}-\mathrm{SV}}{\mathrm{n}} \\
\mathrm{D}_{\mathrm{SL}}=\frac{\text { Rp. } 18.330 .570 .890-0}{20} \\
\mathrm{D}_{\mathrm{SL}}=\text { Rp. } 916.528 .545,-
\end{gathered}
$$

\section{Biaya penyusutan bangunan}$$
\mathrm{D}_{\mathrm{SL}}=\frac{\mathrm{Rp} \cdot 8.462 .138 .088,-0}{20}
$$$$
\mathrm{D}_{\mathrm{SL}}=\text { Rp. 423.106.904, - }
$$

Untuk mesin pabrik penggilingan padi RPC Anabanua kabupaten Wajo yang berlisensi Korea dengan nilai investasi mesin sebesar Rp. 18.330.570.890,-, dengan asumsi nilai akhir aset sama dengan 0 (nol) memiliki biaya penyusutan mesin sebesar Rp. 916.528.545,-per tahun untuk umur ekonomis selama 20 tahun. Sedangkan bangunan pabrik penggilingan padi RPC Anabanua kabupaten Wajo yang dengan nilai investasi bangunan sebesar Rp. 8.462.138.088,-, dengan asumsi nilai akhir aset sama dengan 0 (nol) memiliki biaya penyusutan bangunan sebesar Rp. $423.106 .904,-$ per tahun untuk umur ekonomis selama 20 tahun.

\section{3) Bunga modal}

Perhitungan bunga modal $\left(I_{\mathrm{S}}\right)$ dilakukan dengan modal investasi sebesar Rp. 30.066.544.230,- dikali suku bunga BI oktober 2015 sebesar 7,5\% dikali 
jumlah periode pembungaan selama 20 tahun. Berikut ini perhitungan untuk bunga modal $\left(I_{\mathrm{S}}\right)$ pada RPC.

$$
\begin{aligned}
& I_{\mathrm{S}}=\mathrm{P} x i x n \\
& I_{\mathrm{S}}=\text { Rp. } 30.066 .554 .230 \times 7,50 \% \times 20 \\
& I_{\mathrm{S}}=\text { Rp. } 56.374 .789 .181
\end{aligned}
$$

Selama 20 tahun beban bunga modal pada RPC Anabanua Kabupaten Wajo sebesar Rp. 45.099.831.345,-. Jadi, untuk beban biaya bunga modal pertahunnya sebesar Rp. 2.254.991.567,--

\section{b. Biaya tidak tetap}

\section{1) Biaya bahan bakar}

\section{Bahan bakar solar}

Bahan bakar solar hanya digunakan apabila genset difungsikan ketika produksi tidak menggunakan listrik. Kebutuhan solar dalam produksi per jam sebanyak 50 liter per jam. Karena kapasitas optimal listrik RPC beroperasi saat ini hanya dibatasi selama 8 jam, dikarenakan apabila melewati jumlah jam tersebut maka akan berdampak pada seringnya listrik padam di wilayah sekitar pabrik RPC dan menganggu aktivitas umum masyarakat. Sehingga, untuk mengoptimalkan sisa waktu produksi yaitu 10 jam produksi per hari RPC membutuhkan bantuan genset untuk beroperasi dengan menggunakan bahan bakar solar.

Untuk sisa kapasitas produksi mesin yang tidak dapat diproduksi dengan menggunakan listrik sebanyak $14.400 .000 \mathrm{~kg}$ per tahun dan harus dibantu dengan menggunakan genset. Jika penggunaan solar 50 liter per jam dikalikan 10 jam per hari dikalikan harga solar per liter sebesar Rp. 9.000, jadi kebutuhan solar per hari sebesar Rp. 4.500.000,-, untuk 30 hari masa kerja selama satu bulan kebutuhan solar per hari sebesar Rp. 135.000.000,-, untuk kebutuhan solar 12 bulan dalam setahun sebesar Rp. 1.620.000.000,-. Jadi total kebutuhan solar untuk memproduksi sebanyak $14.400 .000 \mathrm{~kg}$ per tahun adalah 180.000 liter.

\section{Bahan bakar sekam}

Bahan bakar sekam merupakan bahan bakar yang digunakan sebagai bahan bakar untuk proses pengeringan (drying) gabah sebelum masuk proses pembersihan gabah (paddy cleaner) dari bahan asing atau gabah hampa yang lolos. Untuk bahan bakar sekam pada RPC tidak membutuhkan biaya untuk pengadaannya, dikarenakan ketersediaan sekam selalu ada disetiap mesin RPC bekerja dari hasil proses pengupasan kulit padi menjadi beras.

\section{2) Biaya listrik}

\section{Biaya penerangan rumah dinas}

Pada Tabel 2, untuk biaya penerangan rumah dinas pada pabrik penggilingan padi RPC Anabanua Kabupaten Wajo tahun 2013-2015 mengalami fluktuatif, dimana pembayaran tertinggi dilakukan pada tahun 2014 sebesar Rp. 2.543.256,- dan pembayaran terendah dibayarkan pada tahun 2013 sebesar Rp. 1.504. 897,--. 
Tabel 2.Biaya penggunaan listrik untuk penerangan rumah dinas pada RPC Anabanua Kabupaten Wajo tahun 2013-2015

\begin{tabular}{|c|c|c|c|}
\hline & 2013 & 2014 & 2015* \\
\hline Bulan & $\begin{array}{c}\text { Listrik Rumah } \\
\text { Dinas RPC(Rp) }\end{array}$ & $\begin{array}{c}\text { Listrik Rumah } \\
\text { Dinas RPC(Rp) }\end{array}$ & $\begin{array}{c}\text { Listrik Rumah } \\
\text { Dinas RPC(Rp) }\end{array}$ \\
\hline Januari & 0 & 203.420 & 240.152 \\
\hline Februari & 0 & 203.420 & 266.056 \\
\hline Maret & 0 & 203.420 & 0 \\
\hline April & 0 & 203.420 & 520.891 \\
\hline Mei & 173.567 & 203.420 & 0 \\
\hline Juni & 179.484 & 203.720 & 529.706 \\
\hline Juli & 179.484 & 0 & - \\
\hline Agustus & 186.612 & 416.995 & - \\
\hline September & 191.100 & 0 & - \\
\hline Oktober & 191.100 & 440.394 & - \\
\hline Nopember & 200.130 & 0 & - \\
\hline Desember & 203.420 & 465.047 & - \\
\hline TOTAL & 1.504 .897 & 2.543 .256 & 1.556 .805 \\
\hline
\end{tabular}

Sumber Data: Dinas Koperasi, UMKM dan Perindustrian, diolah 2015

*untuk tahun 2015, Data bulan Juli dan sementara tahun berjalan

\section{Biaya listrik produksi}

Kebutuhan listrik produksi pada pabrik penggilingan padi RPC Kabupaten Wajo hanya membutuhkan untuk kapasitas produksi 8 jam per hari. Hal ini dikarenakan, apabila pabrik RPC menggunakan listrik untuk melakukan produksi melebih dari 8 jam per hari maka efeknya dapat memadamkan listrik disekitar pabrik sehingga mengganggu aktifitas malam masyarakat sekitar.

Jika penggunaan listrik untuk 8 jam per hari dengan beroperasi 30 hari per bulan selama 12 bulan per tahun, RPC memiliki jam produksi per tahun untk penggunaan listrik sebesar 2.880 atau hanya mampu berproduksi beras sebesar $11.520 .000 \mathrm{~kg}$. Biaya listrik produksi per $\mathrm{kg}$ sebesar Rp. 83, untuk memproduksi sebesar $11.520 .000 \mathrm{~kg}$ maka biaya yang dibutuhkan sebanyak Rp. 956.160.000,-. Sedangkan sisanya sebesar 14.400.000 kg harus dibantu dengan genset yang menggunakan bahan bakar solar untuk memproduksinya.

\section{3) Biaya pemeliharaan mesin}

Agar kapasitas dan kualitas mesin tetap terjaga, pemeliharaan mesin memiliki peran yang sangat penting untuk dilakukan. Pada Tabel 16, komponen mesin RPC yang membutuhkan pemeliharaan rutin antara lain pada komponen mesin Paddy Husler(mesin pengupas kulit gabah) yaitu Rubber Roll(rol karet), dan kompnen mesin Polisher (mesin pemisahan kulit ari) yaitu Saringan Beras Steenlessdan Saringan Poles.Kapasitas produksi pemakaianRubber Roll yaitu 60-70 ton per pasang, sedangkan Rubber Roll yang digunakan pada mesin RPC Anabanua Kabupaten Wajo sebanyak 3 pasang, sehingga dalam satu tahun produksinya jumlah Rubber Rolldibutuhkan sebanyak 432 pasang. 
Tabel 3. Kebutuhan komponen pemeliharaan mesin pada RPC Anabanua Kabupaten Wajo per tahun

\begin{tabular}{|c|c|c|c|c|c|}
\hline \multirow{2}{*}{ No. } & \multirow{2}{*}{ URAIAN } & \multicolumn{2}{|c|}{ Kebutuhan } & \multirow{2}{*}{$\begin{array}{l}\text { Satuan } \\
\text { (Rp) }\end{array}$} & \multirow{2}{*}{$\begin{array}{c}\text { Jumlah } \\
\text { (Rp) }\end{array}$} \\
\hline & & Jumlah & Unit & & \\
\hline 1 & Rubber Roll & 432 & pasang & 1.000 .000 & 432.000 .000 \\
\hline \multirow[t]{3}{*}{2} & Saringan Beras Steenless & & & & \\
\hline & Besar & 6 & pasang & 750.000 & 4.500 .000 \\
\hline & Kecil & 18 & pasang & 300.000 & 5.400 .000 \\
\hline 3 & Saringan Poles & 2 & pasang & 1.000 .000 & 2.000 .000 \\
\hline \multicolumn{5}{|c|}{ TOTAL } & 443.900.000 \\
\hline
\end{tabular}

Sumber Data: Data Primer, Diolah 2015

Sedangkan pada komponen mesin Paddy Husler yaitu Saringan Beras Steenless terdiri dari 3 pasang ukuran besar dan 9 pasang ukuran kecil untuk penggunaan selama 6 bulan, jadi untuk penggunaan selama satu tahun produksi membutuhkan 6 pasang ukuran besar dan 18 pasang ukuran kecil. Komponen lain yang membutuhkan perawatan rutin pada mesin Paddy Husler yaitu saringan poles sebanyak 2 pasang untuk pemakaian satu tahun produksi.

\section{c. Biaya total}

Biaya total merupakan jumlah biaya tetap dengan biaya tidak tetap produksi pada pabrik penggilingan padi RPC Anabanua Kabupaten Wajo.

Tabel 4. Biaya tetap dan biaya tidak tetap pada RPC sebagai penyedia jasa sewa penggilingangabah

\begin{tabular}{|l|r|}
\hline \multicolumn{1}{|c|}{ BIAYA TETAP } & \multicolumn{1}{|c|}{ JUMLAH (Rp) } \\
\hline Gaji Karyawan & 56.700 .000 \\
\hline Biaya Administrasi & - \\
\hline Biaya Penyusutan Mesin & 916.528 .545 \\
\hline Biaya Penyusutan Bangunan & 423.106 .904 \\
\hline Biaya Bunga & 2.254 .991 .567 \\
\hline Pajak SUB TOTAL & - \\
\hline \multicolumn{1}{|c|}{ SUB TOTAL } & $\mathbf{3 . 6 5 1 . 3 7 2 . 0 1 6}$ \\
\hline Bahan Baku Gabah & 956.160 .000 \\
\hline Bahan Kemasan (Zak + Benang) & 2.543 .256 \\
\hline Biaya Listrik & 1.620 .000 .000 \\
\hline Penerangan rumah dinas & 443.000 .000 \\
\hline Bahan Bakar Minyak & - \\
\hline Biaya Pemeliharaan (Spare Part) & $\mathbf{3 . 0 2 2 . 6 0 3 . 3 5 6}$ \\
\hline Biaya Buruh TOTAL & $\mathbf{6 . 6 7 3 . 9 3 0 . 2 7 2}$ \\
\hline \multicolumn{1}{|c|}{ BIAYA TOTA } \\
\hline
\end{tabular}

Sumber Data: Data sekunder dan data primer, diolah 2015

Pada Tabel 4, biaya total produksi pada RPC sebagai penyedia jasa sewa penggilingan padi sebesar Rp. 6.673.930.272,-- per tahun. Karena kapasitas optimum penggilingan RPC sebesar $25.920 .000 \mathrm{~kg}$ per tahun maka biaya minimal per unit produksi sewa penggilingan gabah RPC sebesar Rp. 257,- 


\section{d. Nilai titik impas produksi untuk jasa sewa penggilingan gabah}

Mesin pabrik penggilingan padi RPC Anabanua Kabupaten Wajo memiliki kapasitas produksi maksimum sebesar $25.920 .000 \mathrm{~kg}$ per tahun, dengan kapasitas produksi 4 ton per jam (4.000 kg per jam) selain memproduksi beras juga dapat menghasilkan produk sampingan yaitu dedak halus sebesar $10 \%$. Untuk mencapai kapasitas produksi maksimum sebesar $25.920 .000 \mathrm{~kg}$ per tahun, maka mesin harus bekerja maksimal selama 12 bulan, sebanyak 30 hari dalam satu bulan dan 18 jam dalam satu hari atau total kerja mesin dalam setahun sebesar 6.480 jam per tahun.

Berdasarkan Perda nomor 9 tahun tentang tarif retribusi penggunaan RPC (Rice Processing Complex) Anabanua yaitu; 1) Sewa giling gabah basah (GKB) Rp. 250,- per kg, 2) Sewa giling gabah kering (GKG) Rp. 200,- per kg, dan 3) Sewa poles beras Rp. 150,- per kg. Berikut ini perhitungan jam kerja mesin per tahun untuk mengetahui jumlah produksi RPC dalam mencapai nilai titik impas pada RPC Anabanua Kabupaten Wajosebagai penydia jasa sewa penggilingan gabah kering panen (GKP) atau gabah basah dan gabah kering giling (GKG).

Nilai titik impas untuk sewa penggilingan Gabah Kering Giling (GKG)

$$
\begin{aligned}
& \mathrm{BEP}=\frac{\mathrm{BT}}{(\mathrm{ks}-\mathrm{BTT})+\mathrm{HS}} \\
& \mathrm{BEP}=\frac{3.651 .372 .016}{(4.000 \times 200-466.477)+0} \\
& \mathrm{BEP}=\frac{2.412 .164 .264}{800.000-466.477} \\
& \mathrm{BEP}=\frac{3.651 .372 .016}{333.523} \\
& \mathrm{BEP}=10.947 \mathrm{jam} / \text { tahun } \\
& \mathrm{BEP} \text { (unit) }=10.947 \times 4.000 \\
& \mathrm{BEP} \text { (unit) }=43.787 .609 \mathrm{~kg} / \text { tahun }
\end{aligned}
$$

Nilai titik impas untuk sewa penggilingan Gabah Kering Panen (GKP)

$$
\begin{aligned}
& \mathrm{BEP}=\frac{3.651 .372 .016}{(4.000 \times 250-466.477)+0} \\
& \mathrm{BEP}=\frac{2.412 .164 .264}{1.000 .000-466.477} \\
& \mathrm{BEP}=\frac{3.651 .372 .016}{533.523} \\
& \mathrm{BEP}=6.843 \mathrm{jam} / \text { tahun } \\
& \mathrm{BEP} \text { (unit) }=6.843 \times 4.000 \\
& \mathrm{BEP} \text { (unit) }=27.373 .889 \mathrm{~kg} / \text { tahun }
\end{aligned}
$$

Untuk jasa sewa giling gabah kering panen (GKP) atau gabah basahsebesar Rp. 250,- yang diterapkan pada RPC Anabanua Kabupaten Wajo dengan berdasarkanPerda nomor 9 tahun 2013, maka dalam hal ini RPC akan selalu mengalami kerugian dikarenakan jam produksi yang harus dilakukan melebihi kapasitas mesin yang dimiliki yaitu sebesar 6.844 jam produksi.Jika di konversi ke dalam $\mathrm{kg}$ gabah yang digiling dengan kapasitas $4.000 \mathrm{~kg}$ per jam dikalikan jam produksi sebesar 6.844 jam maka jumlah minimal gabah yang digiling sebesar $27.373 .889 \mathrm{~kg}$ per tahun untuk mencapai nilai titik impas. Begitupula dengan harga sewa penggilingan gabah kering giling (GKG) sebesar 
Rp. 200,- untuk memperoleh nilai titik impas RPC harus berproduksi sebesar 43.787.609 kg per tahun. Jumlah produksi tersebutmelebihi kapasitas maksimum pabrik penggilingan padi RPC sebesar $25.920 .000 \mathrm{~kg}$ per tahun. Artinya dengan harga jasa sewa penggilingan gabah pada RPC Anabanua sebesar Rp. 200,- dan Rp. 250,- per kg tidak akan dapat mencapai nilai titik impas produksinya.

Jika jasa yang disiapkan sewa penggilingan gabah kering penen dengan poles (GKP+Poles) sebesar Rp. 400,- per kg dimana jasa paket sewa penggilingan gabah kering panen dengan poles (GKP+Poles) merupakan nilai sewa penggilingan gabah kering penen (GKP) sebesar Rp. 250,- ditambah dengan nilai jasa sewa poles beras sebesar Rp. 150,-. maka RPC dapat mencapai nilai titik impas produksinya sebesar $12.884 .586 \mathrm{~kg}$ per tahun dan kapasitas menganggur atau yang belum terpakai sebesar $13.035 .414 \mathrm{~kg}$ per tahun, sebagaimana terlihat pada Tabel 5 berikut ini.

Tabel 5. Nilai titik impas berdasarkan beberapa nilai harga untuk jasa sewa penggilingan gabah RPC Anabanua Kabupaten Wajo

\begin{tabular}{|c|c|c|c|c|c|c|c|c|}
\hline $\begin{array}{c}\text { Jenis Sewa } \\
\text { Penggilingan }\end{array}$ & $\begin{array}{c}\text { Harga } \\
\text { Sewa } \\
\text { Giling } \\
\text { GKG } \\
\text { (Kg) } \\
\end{array}$ & $\begin{array}{c}\text { Biaya } \\
\text { Tidak } \\
\text { tetap } \\
\text { Produksi } \\
(\mathrm{Rp} / \mathrm{Kg}) \\
\end{array}$ & $\begin{array}{c}\text { Margin } \\
\text { Kontrib } \\
\text { usi } \\
(\mathbf{R p} / \mathbf{K g})\end{array}$ & $\begin{array}{l}\text { Nilai BEP } \\
\text { Sewa Giling } \\
\text { (Kg/Tahun) }\end{array}$ & $\begin{array}{c}\text { Jam kerja } \\
\text { mesin pr } \\
\text { tahun } \\
\text { (jam/tahun) }\end{array}$ & $\begin{array}{c}\text { Kapasitas } \\
\text { Optimum } \\
\text { Produksi } \\
\text { (Kg } \\
\text { /Tahun) } \\
\end{array}$ & $\begin{array}{c}\text { Kapasitas } \\
\text { kerja } \\
\text { mesin per } \\
\text { tahun } \\
\text { (jam/tahun) }\end{array}$ & $\begin{array}{c}\text { Kapasitas } \\
\text { menganggur } \\
\text { (idle) } \\
\text { (Kg/Tahun) }\end{array}$ \\
\hline $\begin{array}{l}\text { Gabah Kering } \\
\text { Penen (GKP) }\end{array}$ & 250 & \multirow{4}{*}{117} & 133 & 27.373 .889 & 6.843 & \multirow{4}{*}{25.920 .000} & \multirow{4}{*}{6.480} & $(1.453 .889)$ \\
\hline $\begin{array}{l}\text { Gabah Kering } \\
\text { Giling (GKG) }\end{array}$ & 200 & & 83 & 43.787 .609 & 10.947 & & & $(17.867 .609)$ \\
\hline GKG + Poles & 350 & & 233 & 15.644 .931 & 3.911 & & & 10.275 .069 \\
\hline GKP + Poles & 400 & & 283 & 12.884 .586 & 3.221 & & & 13.035 .414 \\
\hline
\end{tabular}

Sumber Data: Diolah 2015

Begitupula denganjasa yang disiapkan adalah jasa paket sewa penggilingan gabah kering giling dengan poles (GKG + Poles) sebesar Rp. 350,per kg dimana jasa paket sewa penggilingan gabah kering giling (GKG) sebesar Rp. 200,- ditambah dengan nilai jasa sewa poles beras sebesar Rp. 150,- maka RPC dapat mencapai nilai titik impas sebesar $15.644 .931 \mathrm{~kg}$ per tahun dan kapasitas menganggur atau yang belum terpakai sebesar $10.275 .069 \mathrm{~kg}$ per tahun.

\section{Analisis Titik Impas RPC Dalam Memproduksi Beras Untuk Jual}

Analisis titik impas RPC dalam memproduksi beras untuk jual merupakan perhitungan nilai titik impas pada kondisi RPC membeli bahan baku gabah untuk di produksi sendiri menjai beras untuk dipasarkan baik melalui distributor maupun langsung ke pengecer.

\section{a. Biaya tetap}

\section{1) Biaya gajikaryawan tetap}

Berdasarkan SK Gubenrnur Sulawesi Selatan 2014, penetapan UMP (Upah Minimum Provinsi) tahun 2015 sebesar Rp. 2.000.000.,- per bulan yang terdiri atas upah pokok dan tunjangan tetap. Jika melihat gaji pengelolah RPC Anabanua Kabupaten Wajo yang diterimanya sejak tahun 2012 sampai 2015 sangatlah jauh dari standar UMP yaitu hanya Rp. 300.000,- per bulan.

Untuk optimalisasi produksi pada pabrik penggilingan padi RPC Anabanua Kabupaten Wajo penting RPC dengan kembali memproduksi beras sendiri sebagaimana yang telah dilakukan pada pendirian awalnya sebagai pabrik 
produsen beras berkualitas yang memiliki peran dalam memediasi kepentingan pemerintah, pengusaha dan petani dalam mendorong Kabupaten Wajo sebagai pusat produsen beras di Sulawesi Selatan.Untuk menjalankan fungsi RPC sebagai mediator kepentingan pemerintah, pengusaha dan petani maka upah untuk pengelola RPC selama ini yang masih jauh dari UMP dilakukan perhitungan ulang agar dapat mendorong peningkatan kinerja dalam mengoperasikan RPC.

Penghitungan gaji untuk posisi bagian operasional produksi, adalah 40\% tambahan dari gaji terendah yaitu buruh didasarkan dari UMP sebesar Rp. 2.000.000,- menjadi Rp. 2.800.000,- per bulan per org.Bagian operasional tersebut, antara lain; bagian Driyer yang bertugas untuk pada proses awal gabah masukpada tempat penampungan (Intake Hopper)sampai proses pembersihan awal(Pre Cleaner), bagian pecah kulit dimana pada bagian ini bertugas setelah proses pemberihan awal, proses pemecah kulit gabah(Paddy/Rice Huller) sampai proses pemisahan benda-benda asing yang masih sempat lolos dari mesinsebelum masuk ke tanki (De Stoner), bagian Polisher-Sorter- Poles bertugas mulai pada proses pemisahan kulit padi (polisher), sampai prosespenetapan tingkat kualitas beras yang diinginkan yang kemudian masuk ke tanki (Lenght Grader), bagian packing beras bertugas pada proses pengemasan beras, bagian penjaga tungku bertugas untuk menjaga tungku untuk pengeringan gabah, bagian teknisi bertugas untuk mengawasi dan memperbaiki mesin RPC agar tetap terjaga mesinnya, bagian bendahara dan administrasi.

Untuk Kepala Produksi yang bertugas mengawasi jalannya proses produksi, Quality Control yang bertugas menjaga kualitas produksi beras RPC,Bagian Pemasaran yang bertugas untuk memasarkan produksi beras RPC dan Bagian $\mathrm{R} \& \mathrm{D}$ (research and Development) bertugas untuk penelitian dan pengembangan RPC mendapatkan gaji 40\% tambahan dari gaji bagian operasional produksi sebesar Rp. 3.920.000,- per bulan per orang.

Tabel 6. Komposisi dan besaran gaji pengelola RPC Anabanua Kabupaten Wajo untuk pertahun

\begin{tabular}{|c|c|c|c|c|c|}
\hline \multirow{3}{*}{$\begin{array}{l}\text { Komposisi Pengelola RPC } \\
\text { Badan Pengawas }\end{array}$} & \multirow{2}{*}{\multicolumn{2}{|c|}{ Jumlah }} & \multicolumn{2}{|c|}{ Bulan } & \multirow{3}{*}{$\begin{array}{l}\begin{array}{l}\text { Tahun } \\
\text { (Rp) }\end{array} \\
79.027 .200\end{array}$} \\
\hline & & & \multirow{2}{*}{$\begin{array}{r}\text { Satuan (Rp) } \\
2.195 .200 \\
\end{array}$} & \multirow{2}{*}{\begin{tabular}{|r|} 
Jumlah (Rp) \\
6.585 .600
\end{tabular}} & \\
\hline & 3 & orang & & & \\
\hline Pimpinan & 1 & orang & 5.488 .000 & 5.488 .000 & 65.856 .000 \\
\hline Administrasi & 1 & orang & 2.800 .000 & 2.800 .000 & 33.600 .000 \\
\hline Bendahara & 1 & orang & 2.800 .000 & 2.800 .000 & 33.600 .000 \\
\hline Kepala Bagian Produksi & 1 & orang & 3.920 .000 & 3.920 .000 & 47.040 .000 \\
\hline - Bag. Driyer & 2 & orang & 2.800 .000 & 5.600 .000 & 67.200 .000 \\
\hline - Bag. Pecah Kulit & 1 & orang & 2.800 .000 & 2.800 .000 & 33.600 .000 \\
\hline - Bag. Polisher-Sorter-Poles & 1 & orang & 2.800 .000 & 2.800 .000 & 33.600 .000 \\
\hline - Bag. Packing Beras & 1 & orang & 2.800 .000 & 2.800 .000 & 33.600 .000 \\
\hline - Bag. Penjaga Tungku & 1 & orang & 2.800 .000 & 2.800 .000 & 33.600 .000 \\
\hline - Bag. Teknisi Mesin & 1 & orang & 2.800 .000 & 2.800 .000 & 33.600 .000 \\
\hline Quality Assurance & 1 & orang & 3.920 .000 & 3.920 .000 & 47.040 .000 \\
\hline Bagian Pemasaran & 1 & orang & 3.920 .000 & 3.920 .000 & 47.040 .000 \\
\hline Bagian R\&D & 1 & orang & 3.920 .000 & 3.920 .000 & 47.040 .000 \\
\hline
\end{tabular}


Sumber Data: Data sekunder da data primer, diolah 2015

Untuk pimpinan sebagai penanggungjawab operasional secara menyeluruh pada pabrik RPC mendapatkan gaji 40\% tambahan dari Rp. 3.920.000,menjadi Rp. 5.488.000,- per bulan per orang. Sedangkan Badan Pengawas sebanyak 3 orang medapatkan gaji sebesar $40 \%$ dari gaji pimpinan RPC. Adapun tambahan gaji untuk Dewan Pengawas akan menyesuaikan dengan kemampuan RPC seperti terlihat pada Tabel 19 di atas.

\section{2) Biaya administrasi}

Biaya administrasi merupakan biaya yang dikeluarkan secara berkala dalam satu tahun periode untuk kebutuhan pencatatan-pencatatan pada RPC. Apabila dialokasikan 200.000,- per hari untuk kebutuhan administrasi dikalikan masa kerja selama 30 hari, jadi kebutuhan administrasi untuk satu bulan sebesar Rp. 6.000.000,-. Untuk 12 bulan atau satu tahun kebutuhan biaya admisnistrasi sebesar Rp. 72.000.000,-.

\section{b. Biaya tidak tetap}

\section{1) Biaya buruh}

Jumlah buruh dibutuhkan dalam pengoperasian RPC dalam memproduksi beras jual sekitar 15 orang dan gaji buruh berdasarkan UMP 2015 sebesar Rp.2.000.000,-.Jadi, untuk gaji buruh pabrik RPC dapat diperkirakan dalam satu bulan sebesar Rp. 30.000.000,- per bulan. Sedangkan total biaya gaji buruh dibutuhkan untuk satu tahun sebesar Rp. 360.000.000,- per tahun.

\section{2) Biaya bahan baku}

\section{Bahanbaku gabah kering giling}

Untuk mencapai kapasitas maksimal produksi pabrik penggilingan padi RPC Anabanua Kabupaten Wajo sebesar 25.920.000 kg per tahun untuk rendemen $65 \%$ membutuhkan stok gabah kering giling (GKG) sebesar $39.876 .923 \mathrm{~kg}$ per tahun.

Berdasarkan data harga Badan Ketahanan Pangan Wajo (2015), di minggu ke I - IV di bulan Oktober 2015, untuk gabah kering giling (GKG) pada penggilingan harga terendah sebesar Rp. 4.200,- per kg dan harga tertingginya sebesar Rp. 5.500,- per kg. Untuk kebutuhan gabah kering giling (GKG) sebesar $39.876 .923 \mathrm{~kg}$ per tahun berdasarkan harga terendah pada penggilingan sebesar Rp. 4.200,- per kg membutuhkan biaya pembelian bahan baku sebesar Rp. 167.483.076.923,-, sedangkan harga tertinggi pada penggilingan sebesar Rp. 5.500,- per kg membutuhkan biaya pembelian bahan baku sebesar Rp. 219.323.076.923,-.

\section{Bahan baku gabah kering panen}

Untuk mencapai kapasitas maksimal produksi pabrik penggilingan padi RPC Anabanua Kabupaten Wajo sebesar $25.920 .000 \mathrm{~kg}$ per tahun dengan nilai sosok $10 \%$ pada gabah kering panen (GKP) menjadi gabah kering giling (GKG) dalam mencapai kadar air 14\% maka membutuhkan stok gabah kering panen (GKP) sebesar 44.307.692 kg per tahun.

Berdasarkan data harga pada Badan Ketahanan Pangan Wajo (2015), di minggu ke I - IV dibulan Oktober 2015, untuk gabah kering panen (GKP) pada tingkat petani harga terendah sebesar Rp. 4.000,- per kg dan harga 
tertingginya sebesar Rp. 5.000,- per kg. Untuk kebutuhan gabah kering panen (GKP) sebesar 44.307.692 kg per tahun berdasarkan harga GKP terendah sebesar Rp. 4.000,- per kg membutuhkan biaya pembelian bahan baku sebesar Rp. 177.230.769.231,-, sedangkan untuk harga GKP tertinggi sebesar Rp. 5.000 ,- per $\mathrm{kg}$ membutuhkan biaya pembelian bahan baku sebesar Rp. 221.538.461.538,-

\section{Bahan Baku Kemasan}

Bahan baku untuk kemasan beras terdiri dari zak kemasan digunakan sebagai pembungkus beras dan benang untuk menjahit setiap kemasan yang diproduksi. Berikut ini Tabel 7 kebutuhan bahan baku kemasan beras isi $25 \mathrm{~kg}$ Tabel 7. Kebutuhan bahan baku kemasan beras isi $25 \mathrm{~kg}$

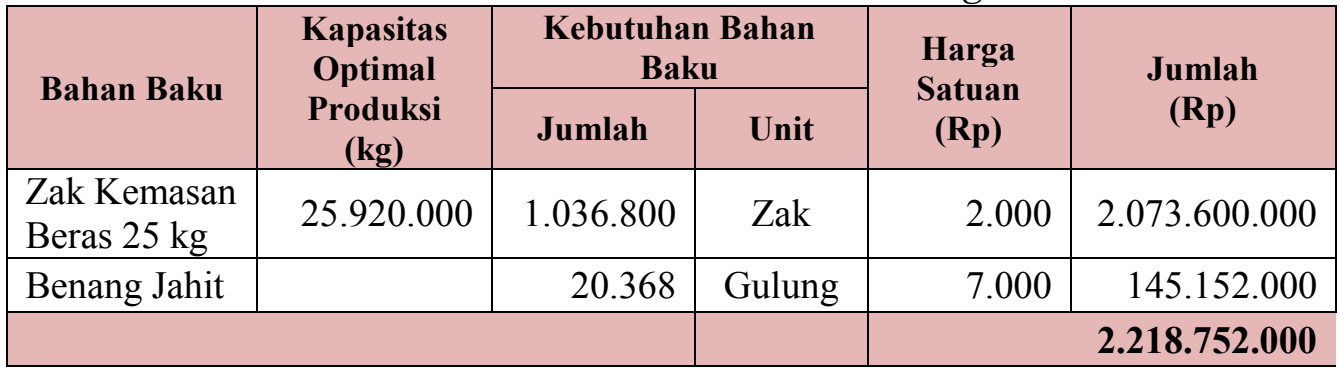

Sumber Data: Data Primer, Diolah 2015

Harga kemasan untuk beras untuk isi $25 \mathrm{~kg}$ sebesar Rp. 2000,- sedangkan kebutuhan bahan baku benang untuk menjahit kemasan beras yaitu harga 1 gulung benang jahit sebesar Rp. 7.000,- per gulung. Dalam proses penjahitan kemasan membutuhkan 2 gulung benang yang dapat menjahit sebanyak 100 zak kemasan beras isi $25 \mathrm{~kg}$. Jadi kebutuhan benang jahit untuk kapasitas optimal produksi pada RPC yang sebesar $25.920 .000 \mathrm{~kg}$ beras dalam satu tahun sebanyak 20.368 gulung benang jahit atau nilai rupiah sebesar Rp. 145.152.000. Sedangkan kebutuhan kemasan beras isi $25 \mathrm{~kg}$ sebanyak 1.0336.800 zak dengan total harga sebesar Rp. 2.073.600.000. Total kebutuhan untuk bahan kemasan beras isi $25 \mathrm{~kg}$ dalam setahun produksi sebesar Rp. 2.218.752.000,-.

\section{3) Biaya distribusi beras}

Biaya distribusi beras merupakan biaya yang dikeluarkan melakukan pendistribusian produk beras RPC ke konsumen.Pada pengusaha beras dari pinrang, dalammendistribusikanberas untuk 10 ton $(10.000 \mathrm{~kg})$ membutuhkan biaya sebesar Rp. 1.000.000,-.Berdasarkan hal tersebut, Jika RPC mendistribusikan sendiri produksi beras untuk dipasarkan makakebutuhan biaya distribusi untuk kapasitas optimum $25.920 .000 \mathrm{~kg}$ beras per tahunmembutuhkan biaya distribusi sebesar Rp. 2.592.000.000,- per tahun atau jika di konversi dalam biaya distribusi per kg sebesar Rp. 100,- per kg.

\section{c. Biaya total}

Biaya total merupakan jumlah biaya tetap dengan biaya tidak tetap produksi pada pabrik penggilingan padi RPC Anabanua Kabupaten Wajo. Pada Tabel 18 memperlihatkan biaya total dalam 4 kategori berdasarkan variasi harga terendah dan tertinggi bahan baku gabah kering giling (GKG) pada tingkat penggilingan dan gabah kering panen (GKP) pada tingkat petani, yaitu harga terendah GKG sebesar Rp. 4.200,-, dan harga tertinggi GKG sebesar Rp. 5.500,-, 
sedangkan untuk harga terendah GKP sebesar Rp. 4.000,- dan harga tertinggi GKP sebesar Rp. 5.000,- (Badan Ketahanan Pangan Kabupaten Wajo, 2015). Adapun biaya total produksi RPC untukmemproduksi beras jual, sebagaimana pada Tabel 8 berikut ini.

Tabel 8. Biaya tetap dan biaya tidak tetap pada RPC untuk produksi beras jual

\begin{tabular}{|c|c|c|c|c|}
\hline \multirow{3}{*}{ BIAYA-BIAYA } & \multicolumn{2}{|c|}{ GABAH KERING GILING (GKG) } & \multicolumn{2}{|c|}{ GABAH KERING PANEN (GKP) } \\
\hline & $\begin{array}{c}\text { Harga terendah } \\
\text { GKG (kg): } \\
\text { Rp. } 4.200\end{array}$ & $\begin{array}{c}\text { Harga Tertinggi } \\
\text { GKG }(\mathrm{kg}): \\
\text { Rp. } 5.500\end{array}$ & $\begin{array}{l}\text { Harga terendah } \\
\text { GKP }(\mathrm{kg}) \text { : } \\
\text { Rp. } 4.000\end{array}$ & $\begin{array}{c}\text { Harga Tertinggi } \\
\text { GKP }(\mathrm{kg}) \text { : } \\
\text { Rp. } 5.000\end{array}$ \\
\hline & JUMLAH (RP) & JUMLAH (RP) & JUMLAH (RP) & JUMLAH (RP) \\
\hline \multicolumn{5}{|l|}{ BIAYA TETAP } \\
\hline Gaji Karyawan & 635.443 .200 & 635.443 .200 & 635.443 .200 & 635.443 .200 \\
\hline Biaya Administrasi & 72.000 .000 & 72.000 .000 & 72.000 .000 & 72.000 .000 \\
\hline Biaya Peny. Mesin & 916.528 .545 & 916.528 .545 & 916.528 .545 & 916.528 .545 \\
\hline \multicolumn{5}{|l|}{ BIAYA TETAP } \\
\hline Biaya Peny. Bangunan & 423.106 .904 & 423.106 .904 & 423.106 .904 & 423.106 .904 \\
\hline Biaya Bunga & 2.254 .991 .567 & 2.254 .991 .567 & 2.254 .991 .567 & 2.254 .991 .567 \\
\hline Pajak & - & - & - & - \\
\hline Sub Total & 4.302. 070.216 & 4.302. 070.216 & 4.302. 070.216 & 4.302. 070.216 \\
\hline Kapasitas Produksi (kg) & 25.920 .000 & 25.920 .000 & 25.920 .000 & 25.920 .000 \\
\hline BT per unit $(\mathrm{kg})$ & 166 & 166 & 166 & 166 \\
\hline \multicolumn{5}{|l|}{ BIAYA TIDAK TETAP } \\
\hline Bahan Baku & 167.483.076.923 & 219.323.076.923 & 177.230 .769 .231 & 221.538 .461 .538 \\
\hline Bahan Kemasan & 2.218 .752 .000 & 2.218 .752 .000 & 2.218 .752 .000 & 2.218 .752 .000 \\
\hline Biaya Listrik produksi & 956.160 .000 & 956.160 .000 & 956.160 .000 & 956.160 .000 \\
\hline By. Listrik Rumah Dinas & 2.543 .256 & 2.543 .256 & 2.543 .256 & 2.543 .256 \\
\hline Biaya Distribusi beras & 2.592 .000 .000 & 2.592 .000 .000 & 2.592 .000 .000 & 2.592 .000 .000 \\
\hline Bahan Bakar Solar & 1.620 .000 .000 & 1.620 .000 .000 & 1.620 .000 .000 & 1.620 .000 .000 \\
\hline $\begin{array}{l}\text { Biaya Pemeliharaan } \\
\text { mesin }\end{array}$ & 443.000 .000 & 443.000 .000 & 443.000 .000 & 443.000 .000 \\
\hline Buruh & 360.000 .000 & 360.000 .000 & 360.000 .000 & 360.000 .000 \\
\hline Sub Total & 175.676 .432 .179 & 227.516 .432 .179 & 185.424 .124 .487 & 229.731 .816 .794 \\
\hline Kapasitas Produksi $(\mathrm{kg})$ & 25.920 .000 & 25.920 .000 & 25.920 .000 & 25.920 .000 \\
\hline BTT per unit (kg) & 6.778 & 8.778 & 7.154 & 8.863 \\
\hline TOTAL BIAYA & 179.978 .502 .395 & 231.818 .502 .395 & 189.726 .194 .703 & 234.033 .887 .011 \\
\hline Total Biaya per unit $(\mathrm{kg})$ & 6.944 & 8.944 & 7.320 & 8.029 \\
\hline
\end{tabular}

Sumber Data: Data Primer, Diolah 2015

\section{d. Nilai Titik Impas Produksi Beras untuk Jual}

Harga jual beras pada tingkat penggilingan padi RMU menurut Badan Ketahatanan Pangan Kabupaten Wajo (2015), antara Rp. 7.100 - Rp. 8.700 per $\mathrm{kg}$. Sedangkan harga beras pembelian Bulog terdiri dari harga beras medium Rp. 7.300,- dan harga beras premium Rp. 9.500,-. Untuk menentukan besaran volume produksi atau jumlah produksi beras pada RPC Anabanua dalam mencapai nilai titik impas, maka perhitungan harga jual beras yang digunakan terdiri dari harga 
jual beras medium Rp. 7.100,- sampai dengan Rp, 7.500,- dan harga jual beras premium Rp. 8.800 sampai dengan Rp. 9.300,-, sebagaimana pada Tabel 9, Tabel 10, Tabel 11 dan Tabel 12 di bawah ini:

Tabel 9. Nilai titik impas berdasarkan harga jual beras medium Rp. 7.100, sampai dengan Rp.7.500,- dan harga gabah kering giling Rp. 4.200,-

\begin{tabular}{|c|c|c|c|c|c|c|c|}
\hline $\begin{array}{c}\text { Harga } \\
\text { GKG } \\
(\mathbf{K g})\end{array}$ & $\begin{array}{c}\text { Jumlah } \\
\text { kebutuhan } \\
\text { Gabah untuk } \\
\text { Optimal } \\
\text { produksi } \\
\text { (kg) } \\
\end{array}$ & $\begin{array}{c}\text { Harga } \\
\text { Jual } \\
\text { Beras } \\
(\mathbf{R P} / \mathbf{K g})\end{array}$ & $\begin{array}{c}\text { Biaya } \\
\text { Tidak } \\
\text { tetap } \\
\text { Produksi } \\
\text { (Rp/Kg) }\end{array}$ & $\begin{array}{c}\text { Margin } \\
\text { Kontribusi } \\
\text { (Rp/Kg) }\end{array}$ & $\begin{array}{c}\text { Nilai BEP } \\
\text { Produksi } \\
\text { (Kg } \\
\text { /Tahun) }\end{array}$ & $\begin{array}{c}\text { Kapasitas } \\
\text { Optimum } \\
\text { Produksi } \\
\text { mesin RPC } \\
\text { (Kg } \\
\text { /Tahun) } \\
\end{array}$ & $\begin{array}{c}\text { Kapasitas } \\
\text { menganggu } \\
\mathbf{r} \text { (idle) } \\
\text { (Kg / Tahun) }\end{array}$ \\
\hline \multirow{5}{*}{4.200} & \multirow{5}{*}{39.876 .923} & 7.100 & \multirow{5}{*}{6.778} & 322 & 13.345 .551 & \multirow{5}{*}{25.920 .000} & 12.574 .449 \\
\hline & & 7.200 & & 422 & 10.185 .793 & & 15.734 .207 \\
\hline & & 7.300 & & 522 & 8.235 .836 & & 17.684 .164 \\
\hline & & 7.400 & & 622 & 6.912 .512 & & 19.007 .488 \\
\hline & & 7.500 & & 722 & 5.955 .578 & & 19.964 .422 \\
\hline
\end{tabular}

Sumber Data: Diolah 2015

Produksi RPC Anabanua Kabupaten Wajo dalam melakukan produksi beras untuk di jual berdasarkan Tabel 22, pada harga jual beras medium Rp. 7.100,- dengan harga bahan baku gabah kering giling (GKG) Rp. 4.200,-, nilai titik impas RPC sebesar $13.345 .551 \mathrm{~kg}$ beras per tahun atau 51,5\% dari 25.920 .000 $\mathrm{kg}$ beras total produksi maksimumnya dan kapasitas menganggur (idle) sebesar 12.574.449 kg untuk produksi beras. Semakin tinggi harga jual beras, maka nilai titik impas produksi RPC juga semakin kecil dan kapasitas menganggur (idle) untuk produksi beras menjadi semakin besar.

Tabel 10. Nilai titik impas berdasarkan harga jual beras medium Rp. 7.100, sampai dengan Rp.7.500,- dan harga gabah kering panen Rp. 4.000,-

\begin{tabular}{|c|c|c|c|c|c|c|c|}
\hline $\begin{array}{l}\text { Harga } \\
\text { GKP } \\
(\mathbf{K g})\end{array}$ & $\begin{array}{c}\text { Jumlah } \\
\text { kebutuhan } \\
\text { Gabah untuk } \\
\text { Optimal } \\
\text { produksi } \\
\text { (kg) } \\
\end{array}$ & $\begin{array}{c}\text { Harga } \\
\text { Jual } \\
\text { Beras } \\
\text { (RP/Kg) }\end{array}$ & $\begin{array}{c}\text { Biaya } \\
\text { Tidak } \\
\text { Tetap } \\
\text { Produksi } \\
\text { (Rp/Kg) }\end{array}$ & $\begin{array}{c}\text { Margin } \\
\text { Kontribusi } \\
\text { (Rp/Kg) }\end{array}$ & $\begin{array}{l}\text { Nilai BEP } \\
\text { Produksi } \\
\text { (Kg } \\
\text { /Tahun) }\end{array}$ & $\begin{array}{c}\text { Kapasitas } \\
\text { Optimum } \\
\text { Produksi } \\
\text { mesin RPC } \\
\text { (Kg } \\
\text { /Tahun) } \\
\end{array}$ & $\begin{array}{c}\text { Kapasitas } \\
\text { menganggur } \\
\text { (idle) } \\
\text { (Kg/Tahun) }\end{array}$ \\
\hline \multirow{5}{*}{4.000} & \multirow{5}{*}{44.307 .692} & 7.100 & \multirow{5}{*}{7.154} & (54) & & \multirow{5}{*}{25.920 .000} & \\
\hline & & 7.200 & & 46 & 92.934 .358 & & $(67.014 .358)$ \\
\hline & & 7.300 & & 146 & 29.407 .521 & & $(3.487 .521)$ \\
\hline & & 7.400 & & 246 & 17.467 .393 & & 8.452 .607 \\
\hline & & 7.500 & & 346 & 12.423 .263 & & 13.496 .737 \\
\hline
\end{tabular}

Sumber Data: Diolah 2015

Tabel 10, pada harga jual beras medium Rp. 7.100,- dengan harga bahan baku gabah kering panen (GKP) Rp. 4.000,-, RPC tidak dapat mencapai nilai titik impasnya dikarenakan margin kontribusinya Rp. -54 per kg. Begitupula dengan harga jual beras medium Rp. 7.200,- dan Rp. 7.300,-, RPC tidak dapat mencapai nilai titik impasnya sebesar $92.934 .358 \mathrm{~kg}$ per tahun dan $29.407 .521 \mathrm{~kg}$ per tahun dikarenakan nilai titik impas produksinya melebihi kapasitas maksimum produksi mesin RPC.

Namun, jika harga jual beras medium sebesar Rp. 7.400,- nilai titik impas produksi RPC sebesar 17.467.393 $\mathrm{kg}$ beras per tahun atau 67,4\% dari 25.920 .000 
kg beras total produksi maksimumnya dan kapasitas menganggur (idle) sebesar 8.452.607 kg untuk produksi beras. Semakin tinggi harga jual beras, maka nilai titik impas produksi RPC juga semakin kecil dan kapasitas menganggur (idle) untuk produksi beras menjadi semakin besar.

Tabel 11. Nilai titik impas berdasarkan harga jual beras premium Rp. 8.800, sampai dengan Rp. 9.200,- dan harga gabah kering giling Rp. 5.500,-

\begin{tabular}{|c|c|c|c|c|c|c|c|}
\hline $\begin{array}{c}\text { Harga } \\
\text { GKG } \\
(\mathbf{K g})\end{array}$ & \begin{tabular}{|c} 
Jumlah \\
kebutuhan \\
Gabah untuk \\
Optimal \\
produksi (kg)
\end{tabular} & $\begin{array}{c}\text { Harga } \\
\text { Jual } \\
\text { Beras } \\
\text { (RP/Kg) }\end{array}$ & $\begin{array}{c}\text { Biaya } \\
\text { Tidak } \\
\text { Tetap } \\
\text { Produksi } \\
\text { (Rp/Kg) } \\
\end{array}$ & $\begin{array}{c}\text { Margin } \\
\text { Kontribusi } \\
\text { (Rp/Kg) }\end{array}$ & $\begin{array}{l}\text { Nilai BEP } \\
\text { Produksi } \\
\text { (Kg } \\
\text { /Tahun) }\end{array}$ & \begin{tabular}{|c|} 
Kapasitas \\
Optimum \\
Produksi \\
mesin RPC \\
(Kg/Tahun)
\end{tabular} & $\begin{array}{c}\text { Kapasitas } \\
\text { menganggur } \\
\text { (idle) } \\
\text { (Kg/Tahun) }\end{array}$ \\
\hline \multirow{5}{*}{5.500} & \multirow{5}{*}{39.876 .923} & 8.800 & \multirow{5}{*}{8.778} & 22 & 192.401 .400 & \multirow{5}{*}{25.920 .000} & $(166.481 .400)$ \\
\hline & & 8.900 & & 122 & 35.159 .160 & & $(9.239 .160)$ \\
\hline & & 9.000 & & 222 & 19.347.332 & & 6.572 .668 \\
\hline & & 9.100 & & 322 & 13.345 .551 & & 12.574 .449 \\
\hline & & 9.200 & & 422 & 10.185 .793 & & 15.734 .207 \\
\hline
\end{tabular}

Sumber Data: Diolah 2015

Sedangkan Tabel 11, pada harga jual beras premium Rp. 8.800,- dengan harga bahan baku gabah kering giling (GKG) Rp. 5.500,-, RPC tidak dapat mencapai nilai titik impasnya dikarenakan produksinya melebihi kapasitas maksimum produksi mesinnya sebesar $192.401 .400 \mathrm{~kg}$ per tahun sedangkan kapasitas produksi hanya sebesar $25.920 .000 \mathrm{~kg}$. Begitupula dengan harga jual beras medium sebesar Rp. 8.900,- RPC tidak dapat mencapai nilai titik impasnya sebesar $35.159 .160 \mathrm{~kg}$ per tahun dikarenakan nilai titik impas produksinya melebihi kapasitas maksimum produksi mesin RPC.

Namun, Jika harga jual beras medium sebesar Rp. 9.000,- nilai titik impas produksi RPC sebesar $19.347 .332 \mathrm{~kg}$ beras per tahun atau 74,6\% dari 25.920 .000 $\mathrm{kg}$ beras total produksi maksimumnya dan kapasitas menganggur (idle) hanya sebesar $6.572 .668 \mathrm{~kg}$ untuk produksi beras. Jadi semakin tinggi harga jual beras, maka nilai titik impas produksi RPC juga semakin kecil dan kapasitas menganggur (idle) untuk produksi beras menjadi semakin besar.

Tabel 12. Nilai titik impas berdasarkan harga jual beras premium Rp. 8.900, sampai dengan $R p$. 9.200,- dan harga gabah kering panen $R p$. 5.000,-

\begin{tabular}{|c|c|c|c|c|c|c|c|}
\hline $\begin{array}{c}\text { Harga } \\
\text { GKP } \\
(\mathrm{Kg})\end{array}$ & $\begin{array}{c}\text { Jumlah } \\
\text { kebutuhan } \\
\text { Gabah untuk } \\
\text { Optimal } \\
\text { produksi (kg) }\end{array}$ & $\begin{array}{c}\text { Harga } \\
\text { Jual } \\
\text { Beras } \\
\text { (RP/Kg) }\end{array}$ & $\begin{array}{c}\text { Biaya } \\
\text { Tidak } \\
\text { Tetap } \\
\text { Produksi } \\
\text { (Rp/Kg) }\end{array}$ & $\begin{array}{c}\text { Margin } \\
\text { Kontrib } \\
\text { usi } \\
(\mathbf{R p} / \mathbf{K g})\end{array}$ & $\begin{array}{c}\text { Nilai BEP } \\
\text { Produksi } \\
\text { (Kg/Tahun) }\end{array}$ & $\begin{array}{c}\text { Kapasitas } \\
\text { Optimum } \\
\text { Produksi } \\
\text { mesin RPC } \\
\text { (Kg/Tahun) }\end{array}$ & $\begin{array}{c}\text { Kapasitas } \\
\text { menganggur } \\
\text { (idle) } \\
\text { (Kg/Tahun) }\end{array}$ \\
\hline \multirow{5}{*}{5.000} & \multirow{5}{*}{44.307 .692} & 8.900 & \multirow{5}{*}{8.863} & 37 & 116.619 .555 & \multirow{5}{*}{25.920 .000} & (90.699.555) \\
\hline & & 9.000 & & 137 & 31.427 .255 & & $(5.507 .255)$ \\
\hline & & 9.100 & & 237 & 18.160 .641 & & 7.759 .359 \\
\hline & & 9.200 & & 337 & 12.769 .963 & & 13.150 .037 \\
\hline & & 9.300 & & 437 & 9.847 .038 & & 16.072 .962 \\
\hline
\end{tabular}

Sumber Data: Diolah 2015

Tabel 12, pada harga jual beras premium Rp. 8.900,- dengan harga gabah kering panen (GKP) Rp. 5.000,-, RPC tidak akan dapat mencapai nilai titik impasnya dikarenakan nilai titik impas produksinya sebesar $116.619 .555 \mathrm{~kg}$ per 
tahun melebihi kapasitas maksimum produksi mesinnya yaitu $25.920 .000 \mathrm{~kg}$. Begitupula dengan harga jual beras premium sebesar Rp. 9.000,-, RPC tidak dapat mencapai nilai titik impasnya sebesar $31.427 .255 \mathrm{~kg}$ per tahun dikarenakan nilai titik impas produksinya melebihi kapasitas maksimum produksi mesin RPC.

Namun, jika harga jual beras premium sebesar Rp. 9.100,- nilai titik impas produksi RPC sebesar $18.160 .641 \mathrm{~kg}$ beras per tahun atau 70,1\% dari 25.920 .000 kg beras total produksi maksimumnya dan kapasitas menganggur (idle) sebesar 7.759.359 kg untuk produksi beras. Jadi semakin tinggi harga jual beras, maka nilai titik impas produksi RPC juga semakin kecil dan kapasitas menganggur (idle) untuk produksi beras menjadi semakin besar.

\section{Penutup}

RPC Anabanua Kabupaten Wajo sebagai penyedia jasa sewa penggilingan padi dengan penerapan harga sewa penggilingan gabah berdasarkan perda nomor 9 tahun 2013 akan selalu mengalami kerugian dalam melakukan produksi. Karena harga sewa penggilingan gabah kering giling (GKG) sebesar Rp. 200,- per kg harus memproduksi sebesar $43.787 .609 \mathrm{~kg}$ per tahun untuk memperoleh nilai titik impas dan untuk harga sewa penggilingan gabah panen (GKP) atau gabah basah sebesar Rp. 250,- per kg harus memproduksi sebesar $27.373 .889 \mathrm{~kg}$ per tahun untuk memperoleh nilai titik impas. Nilai titik impas produksi pada harga sewa Rp. 200,- dan Rp. 250,- tersebut melebihi kapasitas terpasang pada mesin RPC sebesar 25.920.000 kg per tahun. Sedangkan, jika RPC dalam memproduksi beras medium yang akan dijual langsung ke konsumen atau melalui distributor dengan harga bahan baku gabah kering giling (GKG) sebesar Rp. 4.200,- dengan harga jual minimal beras medium sebesar Rp. 7.100,- maka nilai titik impas produksinya sebesar $13.345 .551 \mathrm{~kg}$ per tahun. RPC dalam memproduksi beras medium yang akan dijual langsung ke konsumen atau melalui distributor dengan harga bahan baku gabah kering panen (GKP) sebesar Rp. 4.000,- maka penetapan nilai harga jual minimal beras medium sebesar Rp. 7.400,-untuk mencapai nilai titik impas produksi sebesar $17.467,393 \mathrm{~kg}$ per tahun. RPC dalam memproduksi beras premium yang akan dijual langsung ke konsumen atau melalui distributor dengan harga bahan gabah kering giling (GKG) sebesar Rp. 5.500,- maka penetapan nilai harga jual minimal beras premium sebesar Rp. 9.000,- untuk mencapai nilai titik impas produksi $19.347 .332 \mathrm{~kg}$ per tahun. Dan RPC dalam memproduksi beras premium yang akan dijual langsung ke konsumen atau melalui distributor dengan harga bahan baku gabah kering panen (GKP) sebesar Rp. 5.000,-- maka penetapan nilai harga jual minimal beras premium sebesar Rp. 9.100,- untuk mencapai nilai titik impas produksi $18.160 .641 \mathrm{~kg}$ per tahun. 


\section{Daftar Pustaka}

Chopra S., Meindl P. Supply chain management, planning and operation. Pearson prentice hall. 2007.

Daewon.Rice Processing Compex,(http://subin-cubin.blogspot.com/2008/06/riceprocessing-complex.html, diakses 1 Oktober 2013). 2008.

Dinas Koperasi, UMKM dan Perindustrian. Data Laporan Bulanan Produksi Penyewaan Penggilingan RPC, Pemerintah Kabupaten Wajo. 2015.

Harnanto, Analisa Laporan Keuangan. Yogyakarta, BPFE. 1987

Kompasiana. RPC Beras 7 Tahun Merugi Pemkab Wajo. (online), (http://regional.kompasiana.com/2011/05/27/rpc-beras-7-tahun-merugikanpemkab-wajo-368330.html, Diakses 16 April 2013), 2011.

NCRI. Report On Financial Analysis Of Rice Parboiling/Processing Systems In Bida Area. Niger State, Nigeria. 2006.

Patiwiri A W. Teknologi Penggilingan Padi. Jakarta, Gramedia Pustaka Utama. 2006.

Purwadaria H K. Teknologi Panen dan Pasca Panen Padi. Makalah disajikan dalam Lokakarya Nasional Upaya Peningkatan Nilai Tambah Pengelolaan Padi, Jakarta. 20-21 Juli 2004.

Salengke. Engineering Economic. Techniques for Project and Business Feasibility Analysis.Makassar, Identitas UNHAS. 2012

Samuelson, \& Nordhaus. Ilmu Ekonomi Mikro. Jakarta, PT. Media Global Edukasi. 2003.

Sutrisno. RPC Sebagai Suatu Alternatif Peningkatan Mutu dan Nilai Tambah Beras. Makalah disajikan dalam Lokakarya Nasional Upaya Peningkatan Nilai Tambah Pengolahan Padi, Jakarta. 20-21 Juli 2004

Yamit Z. Manajemen Operasi dan Produksi.Edisi kedua. Cetakan ketiga, EKONISA, Yogyakarta. 2007. 